\title{
ASSESSMENT OF SELECTED B CELLS POPULATIONS IN THE WORKERS OF X-RAY DEPARTMENTS
}

\section{PIOTR KŁUCIŃSKI ${ }^{1}$, BOGDAN MAZUR ${ }^{2}$, LUKASZ SĘDEK $^{3}$, MAŁGORZATA APTEKORZ ${ }^{1}$, PAWEŁ CIEŚLIK ${ }^{4}$, ANTONI H. HRYCEK ${ }^{4}$, and GAYANE MARTIROSIAN ${ }^{1}$}

\author{
${ }^{1}$ Medical University of Silesia, Katowice, Poland \\ Department of Medical Microbiology \\ ${ }^{2}$ Medical University of Silesia, Zabrze, Poland \\ Department of Microbiology and Immunology \\ ${ }^{3}$ Medical University of Silesia, Zabrze, Poland \\ Department and Clinic of Pediatrics Hematology and Oncology \\ ${ }^{4}$ Medical University of Silesia, Katowice, Poland \\ Department and Clinic of Internal, Autoimmune and Metabolic Diseases
}

\begin{abstract}
Objectives: Workers of X-ray departments are occupationally exposed to long-term low levels of ionizing radiation (LLIR), which may affect their humoral immunity. The aim of the study was to assess the influence of LLIR on the number and proportion of B cells (CD19+), B1 cells (CD5+CD19+) and memory B cells (CD27+CD19+) in peripheral blood of such workers. Materials and Methods: In the study group of $47 \mathrm{X}$-ray departments workers and the control group consisting of 38 persons, the number and percentage of CD19+, CD5+CD19+, CD27+CD19+ cells as well as $\mathrm{CD} 5+\mathrm{CD} 19+/ \mathrm{CD} 19+$ and $\mathrm{CD} 27+\mathrm{CD} 19+/ \mathrm{CD} 19+$ cell ratios were assessed using flow cytometry. Additionally, the study group was divided into 2 groups by the length of employment below and over 15 years and analysis adjusted for age and smoking habit was performed. Results: The total number of CD19+ cells showed significant increase in the group of workers in comparison with the persons from the control group, whereas the percentage of CD5+CD19+ cells as well as CD27+CD19+/CD19+ and CD5+CD19+/CD19+ cell ratios were lower. Percentage, number of CD5+CD19+ cells and CD5+CD19+/CD19+ cell ratio were significantly lower in the workers with length of employment longer than 15 years in comparison with those employed below 15 years. Moreover, we found positive associations between the number of CD19+ cells and employment as well as smoking habit, whereas the number of CD5+CD19+ cells was positively associated with cigarette smoking alone. Percentage of CD5+CD19+ cells as well as CD5+CD19+/CD19+ and CD27+CD19+/CD19+ cell ratios were negatively correlated with employment. Conclusions: The study suggests association between the suppressive influence of low level ionizing radiation on circulating in peripheral blood, especially of B1 cells as well as of memory $\mathrm{B}$ cells, in workers of $\mathrm{X}$-ray units, which is adverse in relation to microbiological threat.
\end{abstract}

Key words:

X-rays exposure, B cells, Humoral immunity

This study was supported by the Medical University of Silesia in Katowice and prepared as part of the research project no. KNW-2-090/10. Study manager: Piotr Kłucínski, MD, Associate Professor.

Received: May 16, 2013. Accepted: January 21, 2014.

Corresponding author: P. Kłuciński, Medical University of Silesia, Department of Medical Microbiology, Medyków 18, 40-752 Katowice, Poland (e-mail: pklucinski@sum.edu.pl). 


\section{INTRODUCTION}

Workers of X-ray departments are occupationally exposed to chronic low level of ionizing radiation (LLIR), which may affect function of their immune system. Of leukocytes, lymphocytes, especially lymphocytes B, showed the greatest sensitivity to ionizing radiation [1-3].

Exposure to LLIR is associated with various adverse effects such as: chromosomal aberrations in lymphocytes, changes in the structure and function of their lysosomal membranes, $\mathrm{T}$ cell receptors (TCR) in T lymphocytes, immunoglobulin B cell receptor (BCR) as well as lower concentrations of immunoglobulin [4-9]. B cells $(\mathrm{CD} 19+)$ are responsible for adaptive, humoral immune response and they are heterogeneous population. The main subtypes of CD19+ cells include B1 and B2 cells. Most B cells expressing molecule CD5 (CD19+CD5+) are classified as B1 cells that are connected with spontaneous production of IgM against bacterial polysaccharides and lipopolysaccharides (against $\mathrm{T}$ non-dependent antigens). Antibodies produced by B1 cells show polyspecificity and low affinities for many different antigens. These cells are involved in prevention of autoimmunization by inhibition of signal transmission through BCR, changes in synthesis of interleukin-10 (IL-10) and elimination of autoantigens by the produced antibodies. However, CD19+CD5 + may also inhibit antitumor immunity. Most B1 cells do not develop into memory B cells [10-12]. B2 cells are classical B lymphocytes involved in immune response against $\mathrm{T}$ dependent antigens associated with production of different classes of immunoglobulins (class switching) and development of memory B cells (CD19+CD27+) [11,13].

The aim of the study was to assess the influence of LLIR on peripheralblood B cell populations: CD19+, CD19+CD5+ and CD19+CD27+ in workers of X-ray units.

\section{MATERIAL AND METHODS}

The study group included 47 workers of X-ray diagnostics units (14 men, 33 women) aged 23-63 years (median age: 41). The period of employment ranged from 1 to 33 years (median length of employment: 14 years). The annual effective dose of X-radiation was below $1 \mathrm{mSv}$. In the study group 11 persons smoked cigarettes (4 men, 7 women). The control group consisted of 38 clinically healthy individuals (10 men, 28 women), not working in radiology, who were never occupationally exposed to ionizing radiation. Nine persons smoked cigarettes (6 women, 3 men). Data concerning the examined groups/subgroups are presented in Tables 1-3. All the participants were subjected to medical examination and underwent basic hematological and biochemical assays to evaluate their state of health. All the subjects' working time was similar. No deviations in the basic laboratory tests (including $\mathrm{C}$ reactive protein; the study group vs. the control group - median: 0.79, range: $0.21-3.2$ vs. median: 0.82 , range: $0.19-3.66 \mathrm{mg} / \mathrm{l}, \mathrm{p}=0.65$ ), no infections month before the study and no acute or chronic diseases were found. Economic and social state and place of residence of all the participants were similar.

Table 1. Characteristics of the study and control groups

\begin{tabular}{lccc}
\hline \multicolumn{1}{c}{ Variable } & $\begin{array}{c}\text { Workers } \\
(\mathrm{N}=47)\end{array}$ & $\begin{array}{c}\text { Control group } \\
(\mathrm{N}=38)\end{array}$ & $\mathrm{p}$ \\
\hline Age (years) $[$ Me (range) & $41(23-63)$ & $40(20-60)$ & 0.33 \\
Male (n) & 14 & 10 & $0.91^{*}$ \\
Smoking habit (n) & 11 & 9 & $0.82^{*}$ \\
\hline
\end{tabular}

Me-median.

* Yates's $\chi^{2}$. 
Table 2. Characteristics of the study and control groups in relation to smoking habit

\begin{tabular}{|c|c|c|c|c|c|c|}
\hline \multirow[b]{2}{*}{ Variable } & \multicolumn{2}{|c|}{ Non-smoking } & \multirow[b]{2}{*}{$\mathrm{p}$} & \multicolumn{2}{|c|}{ Smoking } & \multirow[b]{2}{*}{$\mathrm{p}$} \\
\hline & $\begin{array}{l}\text { workers } \\
(\mathrm{N}=36)\end{array}$ & $\begin{array}{c}\text { control } \\
(\mathrm{N}=29)\end{array}$ & & $\begin{array}{l}\text { workers } \\
(\mathrm{N}=11)\end{array}$ & $\begin{array}{l}\text { control } \\
(\mathrm{N}=9)\end{array}$ & \\
\hline Age (years) [Me (range)] & $39.5^{\mathrm{a}}(23-63)$ & $40^{\mathrm{b}}(21-60)$ & 0.44 & $40^{\mathrm{a}}(25-55)$ & $43^{\mathrm{b}}(20-60)$ & 0.55 \\
\hline $\begin{array}{l}\text { Smoking habit (pack-years) } \\
\text { [Me (range)] }\end{array}$ & - & - & - & $10(1-30)$ & $10(2-30)$ & 0.76 \\
\hline Male & 13 & 5 & $0.16^{*}$ & - & - & - \\
\hline
\end{tabular}

${ }^{\mathrm{a}} \mathrm{p}=0.80 ;{ }^{\mathrm{b}} \mathrm{p}=0.84$

Other abbreviations as in Table 1.

Table 3. Characteristics of the study groups in relation to the period of employment

\begin{tabular}{|c|c|c|c|}
\hline Variable & $\begin{array}{c}\text { Workers }<15 \text { years } \\
\text { of employment } \\
(\mathrm{N}=29)\end{array}$ & $\begin{array}{c}\text { Workers }>15 \text { years } \\
\text { of employment } \\
(\mathrm{N}=18)\end{array}$ & $\mathrm{p}$ \\
\hline Male (n) & 8 & 6 & $0.89 *$ \\
\hline Smoking habit (n) & 7 & 4 & $1.00^{* *}$ \\
\hline $\begin{array}{l}\text { Length of employment (years) } \\
\text { [Me (range)] }\end{array}$ & $8(1-14)$ & $25(16-33)$ & \\
\hline
\end{tabular}

The evaluated laboratory parameters included: the number and percentage of circulating in peripheral blood: B cell populations: CD19+, CD19+CD5+ and $\mathrm{CD} 19+\mathrm{CD} 27+$.

Blood samples from antecubital vein were collected between 8:00-9:00 a.m. into the test tubes with EDTA (Ethylenediaminetetraacetic acid) and later B cells were labelled with monoclonal antibodies CD19FITC, CD5PE and CD27PerCP (Becton-Dickinson, USA). Analysis was performed by the use of BD FACS Canto II flow cytometer (Becton-Dickinson, San Jose, CA, USA) and 100000 cells per tube were acquired.

\section{Statistical analysis}

The results were compared in the following manner:

1. Between the total group of workers (47 persons) and the control group (38 persons).
2. Between the subgroup of 29 workers employed less than 15 years and 18 workers employed longer than 15 years.

3. Final multivariate regression analysis used to examine whether the percentage and absolute number of $\mathrm{CD} 19+, \mathrm{CD} 19+\mathrm{CD} 27+, \mathrm{CD} 5+\mathrm{CD} 19+$ as well as $\mathrm{CD} 19+\mathrm{CD} 27+/ \mathrm{CD} 19+$ and CD5+CD19+/CD19+ cell ratios were independently associated in workers with their employment length, age and smoking habit. The results are presented as medians with minimal and maximal values (Shapiro-Wilk test did not show normal distribution) and regression coefficients. The statistical analysis was performed using the following tests: Yates's $\chi^{2}$, Fisher, U Mann-Whitney test and regression coefficient in a multivariate linear analysis model adjusted to employment, age and smoking habit; $p$ values of $<0.05$ were considered as 
significant. Statistica 10 software was used to carry out the analyses.

The study was approved by the Ethics Commission of the Medical University of Silesia (KNW/0022/KB1/160/08) and it was carried out in compliance with the Declaration of Helsinki.

\section{RESULTS}

The statistical analysis of the number of CD19+ cells showed a significant increase $(p<0.01)$ in the study group of workers in comparison with the persons from the control group, whereas the percentage of CD5+CD19+ $(p<0.05)$, $\mathrm{CD} 27+\mathrm{CD} 19+/ \mathrm{CD} 19+(\mathrm{p}<0.05)$ and CD5+CD19+/ CD19+ $(\mathrm{p}<0.01)$ cell ratios were lower. Workers with the length of employment longer than 15 years showed a significantly lower percentage $(\mathrm{p}<0.01)$ and the number $(\mathrm{p}<0.05)$ of CD5+CD19+ lymphocytes and CD5+CD19+/CD19+ cell ratio $(\mathrm{p}<0.01)$ in comparison with those with the length of employment less than 15 years (Table 4).

The multivariate regression analysis in the group of workers showed that the number of CD19+ cells ( $p<0.05$ ) was positively associated with the length of employment and smoking habit. We also found a negative association between the percentage of $\mathrm{CD} 5+\mathrm{CD} 19+$ cells and CD5+CD19+/ CD19+ cell ratio, as well as CD27+CD19+/CD19+ cell ratio $(p<0.05)$ with the length of employment. The number of CD5+CD19+ cells $(p<0.05)$ was positively associated with cigarette smoking. Although we proved a significant positive relationship ( $\beta$ (SE): 0.808 (0.088); $p<0.001$ ) between the age and the length of employment in the study group, we did not find any associations between the workers' age and the percentages and absolute numbers of CD19+, CD19+CD27+, CD5+CD19+, CD19+CD27+/CD19+ and $\mathrm{CD} 5+\mathrm{CD} 19+/ \mathrm{CD} 19+$ cell ratios (Tables 5 and 6). Moreover, no significant relationships were found between the analyzed parameters and age as well as cigarette smoking in the control group (data not shown).

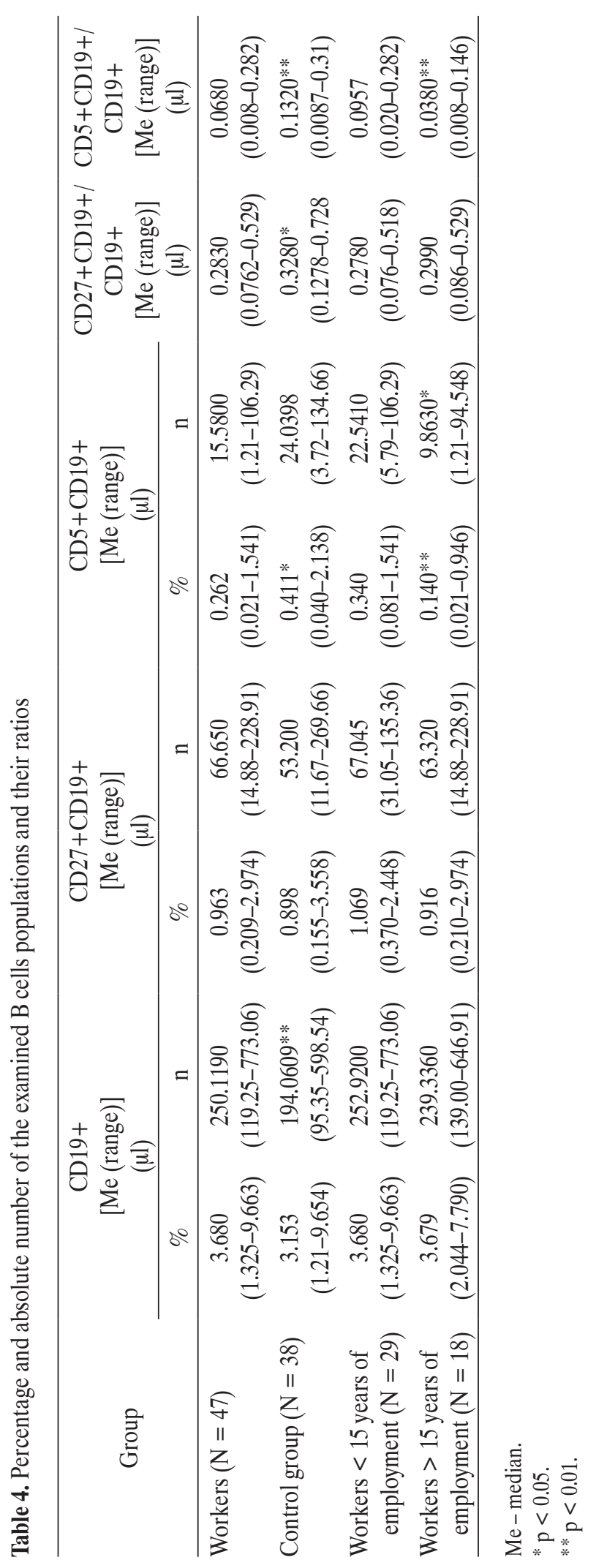


Table 5. Regression coefficient $\beta$ and standard error (SE) for the percentage and absolute number of CD19+, CD19+CD27+ and CD5+CD19+ cells in the multivariate linear regression model adjusted to the employment, age and smoking habit

\begin{tabular}{lcccccc}
\hline \multirow{2}{*}{ B cells } & \multicolumn{2}{c}{$\begin{array}{c}\text { Employment } \\
\text { N (SE) }\end{array}$} & \multicolumn{2}{c}{$\begin{array}{c}\text { Age } \\
\beta(\mathrm{SE})\end{array}$} & \multicolumn{2}{c}{$\begin{array}{c}\text { Smoking habit } \\
\beta(\mathrm{SE})\end{array}$} \\
\cline { 2 - 7 } & $\%$ & $\mathrm{n}$ & $\%$ & $\mathrm{n}$ & $\%$ & $\mathrm{n}$ \\
\hline $\mathrm{CD} 19+(\mu \mathrm{l})$ & $0.161(0.110)$ & $0.234(0.106)^{*}$ & $-0.068(0.111)$ & $-0.057(0.108)$ & $0.109(0.111)$ & $0.219(0.107)^{*}$ \\
$\mathrm{CD} 19+\mathrm{CD} 27+(\mu \mathrm{l})$ & $-0.032(0.112)$ & $0.039(0.112)$ & $0.009(0.113)$ & $-0.032(0.113)$ & $-0.053(0.113)$ & $0.068(0.113)$ \\
$\mathrm{CD} 5+\mathrm{CD} 19+(\mu \mathrm{l})$ & $-0.214(0.106)^{*}$ & $-0.158(0.106)$ & $-0.134(0.108)$ & $-0.118(0.107)$ & $0.181(0.107)$ & $0.267(0.107)^{*}$ \\
\hline
\end{tabular}

$* \mathrm{p}<0.05$.

Table 6. Regression coefficient $\beta$ and standard error (SE) for CD19+CD27/CD19+ and CD5+CD19+/CD19+ cell ratios in the multivariate linear regression model adjusted to the employment, age and smoking habit

\begin{tabular}{cccc}
\hline \multicolumn{1}{c}{ Ratio } & $\begin{array}{c}\text { Employment } \\
\beta(\mathrm{SE})\end{array}$ & $\begin{array}{c}\text { Age } \\
\beta(\mathrm{SE})\end{array}$ & $\begin{array}{c}\text { Smoking habit } \\
\beta(\mathrm{SE})\end{array}$ \\
\hline $\mathrm{CD} 19+\mathrm{CD} 27+/ \mathrm{CD} 19+(\mu \mathrm{l})$ & $-0.236(0.108)^{*}$ & $0.089(0.110)$ & $-0.114(0.109)$ \\
$\mathrm{CD} 5+\mathrm{CD} 19+/ \mathrm{CD} 19+(\mu \mathrm{l})$ & $-0.395(0.102)^{*}$ & $0.059(0.103)$ & $0.114(0.103)$ \\
\hline
\end{tabular}

$* \mathrm{p}<0.05$.

\section{DISCUSSION}

The increase in the total number of CD19+ cells along with the associated decrease of CD5+CD19+ cells percentage and $\mathrm{CD} 27+\mathrm{CD} 19+/ \mathrm{CD} 19+$ as well as $\mathrm{CD} 5+\mathrm{CD} 19+/ \mathrm{CD} 19+$ cell ratios in the study group may suggest $B$ cells dysfunction in the immune response against both non T-dependent and T-dependent antigens. It should be emphasized that exposure to LLIR is associated with significantly lower concentrations of $\operatorname{IgM}, \operatorname{IgG}$ and IgA immunoglobulins and radiology units are possible sources of microbial cross transmission $[8,9,14,15]$. These changes do not seem advantageous in X-ray departments workers because this type of humoral immunity is crucial in defense against extracellular multiplying pathogens including multidrug resistant bacteria (Staphylococcus aureus, Enterococcus spp., Klebsiella pneumoniae, Escherichia coli, etc.) and some viruses (influenza virus). For the employees of radiology units they may be associated with the risk of healthcare associated infections $[14,15]$.
The observed higher number of CD19+ cells among workers may be a result of changes in expression of adhesive molecules that influence the number of $\mathrm{B}$ cells circulating in peripheral blood [16,17]. The decreased $\mathrm{CD} 27+\mathrm{CD} 19+/ \mathrm{CD} 19+$ cell ratio, which suggests impaired development of Th2 and humoral memory connected with CD27+CD19+ lymphocytes, is particularly adverse. No significant differences found in B cells of the exposed to LLIR workers and the control group are associated with the diversity of these cells $[5,8]$. The observed decrease of CD5+CD19+ cells percentage as well as of CD27+CD19+/CD19+ and CD5+CD19+/ $\mathrm{CD} 19+$ cell ratios may result from the lower serum level of interleukin - 4 (IL-4) and IL-10 and higher interleukin - 2 (IL-2) because IL-4 and IL-10 are pivotal for Th2 immune response and function of B cells, whereas IL-2 prefers Th1 and inhibits Th2 immune response [5,18]. Tobacco smoking reduces the level of $\operatorname{IgG}$ in human serum, whereas proportion of $\mathrm{B}$ cells in the peripheral blood of smokers was similar to that in the non-smokers [19]. 
In our study we showed that smoking habit in employees was associated with the increase in the number of $\mathrm{CD} 19+$ and CD5+CD19+ cells. Additionally, it may confirm the dysfunction of $\mathrm{B}$ cells, which is manifested by the lower immunoglobulin production in spite of low intensity of tobacco smoking in our study group [8,9].

The multivariate linear regression revealed that within the study group, the length of employment may correlate with the decrease of CD5+CD19+ cells percentage, CD5+CD19+/CD19+ and CD27+CD19+/CD19+ cell ratios and the increase in total CD19+ cell number, while these values are not associated with the age of workers and persons from the control group. Gupta et al. [20] also have not shown significant differences in the percentage of CD5+CD19+ and CD5+CD19+/ $\mathrm{CD} 19+$ cell ratio in normal peripheral blood with reference to age groups below 40 and over 40 years of age (range: 23-69 years).

The observed decrease in B1 cells percentage may result from apoptosis or immunoregulatory processes among these cells, associated with the induction of free radicals and lower activity of antioxidant enzymes observed in X-ray department workers [21-23]. Moreover, Torkabadi et al. [24] have observed higher percentages of $\mathrm{CD} 4+\mathrm{CD} 25+$ cells (regulatory $\mathrm{T}$ cells) in angiography personnel exposed to LLIR, which may have suppressive influence on B cells proliferation. Analysis of CD5+CD19+ cells in the subgroup of workers employed more than 15 and below 15 years confirms this tendency.

\section{CONCLUSIONS}

The study suggests a relationship between the low level of ionizing radiation and humoral immunity manifested as reduction of $\mathrm{CD} 5+\mathrm{CD} 19+$ cells and $\mathrm{CD} 27+\mathrm{CD} 19+/$ CD19+ cell ratio, which may be a risk factor of microbial threat.

\section{REFERENCES}

1. Stewart C, Stevenson A, Habbersett R. The effect of low-dose irradiation on unstimulated and PHA-stimulated human lymphocyte subsets. Int J Radiat Biol Relat Stud Phys Chem Med. 1988;53(1):77-87, http://dx.doi. org/10.1080/09553008814550441.

2. Gridley D, Pecaut M, Nelson G. Total-body irradiation with high-LET particles: acute and chronic effects on the immune system. Am J Physiol Regul Integr Comp Physiol. 2002;282(3):R677-R88.

3. Hrycek A, Stieber M. [Selected problems concerning X-ray influence on leukocytes]. Wiad Lek. 1994;47(7-8):288-91. Polish.

4. Maffei F, Angelini S, Cantelli FG, Violante FS, Lodi V, Mattioli S, et al. Spectrum of chromosomal aberrations in peripheral lymphocytes of hospital workers occupationally exposed to low doses of ionizing radiation. Mutat Res. 2004;547 (1-2):91-9, http://dx.doi.org/10.1016/j.mrfmmm.2003.12.003.

5. Zakeri F, Hirobe T, Akbari Noghabi K. Biological effects of low-dose ionizing radiation exposure on interventional cardiologists. Occup Med. 2010;60(6):464-9, http://dx.doi. org/10.1093/occmed/kqq062.

6. Facchini A, Maraldi N, Bartoli S, Farulla A, Manzoli F. Changes in membrane receptors of $\mathrm{B}$ and $\mathrm{T}$ human lymphocytes exposed to 60Co gamma rays. Radiat Res. 1976;68(2):339-48, http://dx.doi.org/10.2307/3574485.

7. Herrera M, Diaz-Perches R, Gutierrez M, Gamminio E, Liera $\mathrm{C}$, Nieto $\mathrm{P}$, et al. The inhibitory effect of ionizing radiation on $\mathrm{Fc}$ and $\mathrm{C} 3$ receptors on mouse and human leukocytes, and the protective potential of human albumin. Exp Hematol. 1990;18(7):853-6.

8. Godekmerdan A, Ozden M, Ayar A, Gursu M, Ozan A, Serhatlioglu S. Diminished cellular and humoral immunity in workers occupationally exposed to low levels of ionizing radiation. Arch Med Res. 2004;35(4):324-8, http://dx.doi. org/10.1016/j.arcmed.2004.04.005.

9. Kłuciński P, Mazur B, Kaufman J, Hrycek A, Cieślik P, Martirosian G. Assessment of blood serum immunoglobulin 
and c-reactive protein concentrations in workers of X-ray diagnostics units. Inter J Occup Med Environ Health. 2005;18(4):327-30.

10. Dalloul A. CD5: A safeguard against autoimmunity and a shield for cancer cells. Autoimmun Rev. 2009;8(4):349-53, http://dx.doi.org/10.1016/j.autrev.2008.11.007.

11. Jasiulewicz A, Lisowska KA, Bryl E, Witkowski JM. [The role of B-lymphocytes in the pathomechanism of selected diseases]. Forum Med Rodz. 2011;5(1):37-46. Polish.

12. Mageed RA, Garaud S, Taher TE, Parikh K, Pers JO, Jamin C, et al. CD5 expression promotes multiple intracellular signaling pathways in B lymphocyte. Autoimmun Rev. 2012;11(11):795-8, http://dx.doi.org/10.1016/ j.autrev.2012.02.007.

13. Veneri D, Ortolani R, Franchini M, Tridente G, Pizzolo G, Vella A. Expression of CD27 and CD23 on peripheral blood B lymphocytes in humans of different ages. Blood Transfus. 2009;7(1):29-34, http://dx.doi.org/10.2450/2008.0007-08.

14. Üstünsöz B. Hospital infections in radiology clinics. Diagn Interv Radiol. 2005;11(1):5-9.

15. Drop A, Czekajska-Chehab E, Staśkiewicz G, Plewik D, Niedźwiadek J, Ligięza J, et al. [Radiology department as a possible source of bacterial flora cross-transmission]. Sepsis. 2009;2(2):71-4. Polish.

16. Friedman EJ. Immune modulation by ionizing radiation and its implications for cancer immunotherapy. Curr Pharm Des. 2002;8(19):1765-80, http://dx.doi.org/ 10.2174/1381612023394089.

17. Reits EA, Hodge JW, Herberts CA, Groothuis TA, Chakraborty M, Wansley EK, et al. Radiation modulates the peptide repertoire, enhances MHC class I expression, and induces successful antitumor immunotherapy.
J Exp Med. 2006;203(5):1259-71, http://dx.doi.org/10.1084/ jem.20052494.

18. Hrycek A, Czernecka-Micińska A, Kłuciński P, Badowski R. Peripheral blood lymphocytes and selected serum interleukins in workers operating X-ray equipment. Toxicol Lett. 2002;132(2):101-17, http://dx.doi.org/10.1016/S03784274(02)00030-9.

19. Barbour SE, Nakashima K, Zhang J, Tangada S, Hahn C, Schenkein HA, et al. Tobacco and smoking: environmental factors that modify the host response (immune system) and have an impact on periodontal health. Crit Rev Oral Biol Med. 1997;8(4):437-60, http://dx.doi.org/10.1177/104544119 70080040501.

20. Gupta R, Jain P, Deo SVS, Sharma A. Flow cytometric analysis of CD5+ B cells. Frame of reference for minimal residual disease analysis in chronic lymphocytic leukemia. Am J Clin Pathol. 2004;121(3):368-72, http://dx.doi.org/10.1309/ T5EM9BQUB9CM8F57.

21. Finkel T. Oxygen radicals and signaling. Curr Opin Cell Biol. 1998;10:248-53.

22. Shankar B, Premachandran S, Bharambe SD, Sundaresan P, Sainis KB. Modification of immune response by low dose ionizing radiation: role of apoptosis. Immunol Lett. 1999;68:237-45.

23. Kłucinski P, Wójcik A, Grabowska-Bochenek R, Gmiński J, Mazur B, Hrycek A, et al. Erythrocyte antioxidant parameters in workers occupationally exposed to low levels of ionizing radiation. Ann Agric Environ Med. 2008;15:9-12.

24. Torkabadi E, Kariminia A, Zakeri F. Alteration of peripheral blood T-reg cells and cytokines production in angiography personnel exposed to scattered X-rays. Iran J Allergy Asthma Immunol. 2007;6(4):181-7.

This work is available in Open Access model and licensed under a Creative Commons Attribution-NonCommercial 3.0 Poland License - http://creativecommons.org/ licenses/by-nc/3.0/pl/deed.en. 